\title{
EFFECTS OF URBAN WASTE ON HEAVY METALS CONCENTRATION IN CARICA PAPAYA LINN AND SOIL IN ENEKA DUMPSITE, PORT HARCOURT, RIVERS STATE, NIGERIA
}

\author{
Olatunde Sunday ELUDOYIN* \\ University of Port Harcourt, Department of Geography and Environmental Management, East-West Road, Choba, Port \\ Harcourt, Nigeria, e-mail: olatunde.eludoyin@uniport.edu.ng \\ Mohammed Abdullah GAFAR \\ University of Port Harcourt, Department of Geography and Environmental Management, East-West Road, Choba, Port \\ Harcourt, Nigeria, e-mail: gafarabdullahi@gmail.com
}

Citation: Eludoyin, O.S., \& Gafar, M.A. (2020). Effects of urban waste on heavy metals concentration in Carica Papaya Linn and soil in Eneka Dumpsite, Port Harcourt, Rivers State, Nigeria. Analele Universităţii din Oradea, Seria Geografie, 30(2), 131-140. https://doi.org/10.30892/auog.302102-840

\begin{abstract}
The study examined the heavy metal concentrations in the tissues of Carica papaya $(\mathrm{CP})$ tissues and soil in Eneka Dumpsite, Port Harcourt, Nigeria. A transect of 100 $\mathrm{m} \times 300 \mathrm{~m}$ was laid from the center of the dumpsite. In the transect a $20 \mathrm{~m}$ x $20 \mathrm{~m}$ quadrat was established at $10 \mathrm{~m}, 20 \mathrm{~m}, 50 \mathrm{~m}$, and $300 \mathrm{~m}$ (control) from the dumpsite whereby the soil samples and CP tissues (leaf, fruit and root) were collected. Standard laboratory techniques were used to determine the heavy metals in the soil samples and CP tissues. Results showed that heavy metals in $\mathrm{CP}$ and soil decreased with increasing distance from the dumpsite. $\mathrm{Fe}, \mathrm{Pb}$ and $\mathrm{Cu}$ in $\mathrm{CP}$ tissues varied significantly with distance. In conclusion, there is accumulation of heavy metals in $\mathrm{CP}$ around dumpsite and human consumption of such CP should be reduced or totally avoided.
\end{abstract}

Key words: dumpsite, heavy metals, carica papaya, human health, medicinal

$$
* \quad * \quad * \quad * \quad * \quad *
$$

\section{INTRODUCTION}

Solid waste disposal releases toxic substances into the environment (Kouznetsova et al, 2007). Toxic substances which include heavy metals accumulate in the environment above their normal level and cause alterations in the air, plants, soil, water and micro-organisms. The heavy metals which have densities higher than $5 \mathrm{~g} / \mathrm{cm}^{3}$, are non-biodegradable and persistently accumulate in the ecosystem; hence heavy metals are serious environmental pollutants (Nubi et al., 2009; Ukpong et al., 2013; Obasi et al., 2013; Aladesanmi et al., 2016; Romocea et al., 2018). The contamination of the soil and plants in the ecosystem may pose health hazards to humans by ingesting the contaminants directly and indirectly through the contaminated soil, food chain (soil-

\footnotetext{
${ }^{*}$ Corresponding Author
} 
plant-human or soil-plant-animal-human), drinking of contaminated groundwater or surface water (Herman et al., 2019a,b,c). Subsequently, the solid waste dumpsite contaminates the soil through disintegration and oxidation processes which in the long run discharge leachate from dumpsites into the neighbouring soils and groundwater (Nagarajan et al., 2012).

The release of heavy metals to the ecosystem would have been reduced in the developing countries but the use of landfill as a way of waste disposal has been a major problem; however open dumps have been the most common method of solid waste disposal.

The threat of heavy metals to the ecosystem would have been reduced especially in the developing countries but the preparation of landfill is a major system of arranging waste in numerous under-developed nations including Nigeria (Adewole, 2009). Thus, open dumps have been the antiquated and commonest way for solid waste dumping. Subsequently, producing solid waste and inadequate dumping system is dangerous to the earth because it leads to ecological contamination particularly in the urban communities (Amadi et al., 2010). Perpetual movements from the provincial ranges to urban zones and population increase in sub-Saharan African nations have aggravated the rate of pollution increase (Awomeso et al., 2010; Najib et al., 2012). Furthermore, lack of extension services and terrible system execution are significant reasons for urban contamination from urban waste especially in Nigeria as this behaviour can result in exposure to heavy metals which exceed health standards.

Studies have shown that dumpsites are used for cultivating crops like cassava, maize and vegetables because of the perceived fertility of the soil in and around the dumpsite (Amadi and Nwankoala, 2013); but this attitude may be deadly if there is no proactive measure to intervene and enlighten the public. This is because the crops absorb heavy metals from the polluted soil and when consumed by man, it could constitute health challenges in the body system (Rotich et al., 2006; Njagi, 2013). It is already established that, the uptake of heavy metals in crops generates a threat to humans and may lead to death of man particularly children. World Health Organization (WHO) assessed that most of the diseases confronting mankind in the recent times came about due to continued contact to environmental contamination (Rotich et al., 2006; PrussUstun and Corvalan, 2006).

Several studies had been carried out on the uptake of heavy metals by crops or plants. This included the study that examined the impacts of dumpsite on spinach, cowpea and potatoes in Mpape dumpsite, Abuja whereby the concentrations of mercury, copper, and cadmium in plants of the dumpsite were above FEPA limit, except spinach that contained Iron and zinc values within the safety limit (Magaji, 2012). Futhermore, the concentration of Cd was more than other heavy metals in all the vegetables investigated (Magaji, 2012). The impacts of dumpsite on the Amaranthus sp vegetable around the dumpsite in Anyigba, Kogi State showed that the concentration of $\mathrm{Fe}, \mathrm{Zn}$ and $\mathrm{Cu}$ at the dumpsite was $7.27 \mathrm{ppm}, 6.53 \mathrm{ppm}$ and $6.53 \mathrm{ppm}$ respectively and higher than that of the abandoned dumpsite; though the heavy metals were found to be within the acceptable limits (Musa and Ifatimehin, 2013). A study considered the ecological status of heavy metals in soil of waste dumpsite in Ido-Osun, Osogbo and it was observed that the concentration of Zn was the highest $(1133 \pm 897 \mathrm{mg} / \mathrm{kg})$ and $\mathrm{Cr}$ was the lowest $(3.63 \pm 2.46 \mathrm{mg} / \mathrm{kg})$ (Olayiwola and Onwordi, 2015). Also, a study investigated the heavy metals contents in both soils and plants in a non-functional waste dumpsites in Port Harcourt whereby the concentrations of $\mathrm{Pb}$ and $\mathrm{Cd}$ in the plants were higher at the dumpsite than the control site (Eshalomi-Mario and Taneel, 2015); while another study assessed various metals on edible leafy plants of Umuka and Ubahu dumpsites in Okigwe, Imo State, Nigeria whereby heavy metals $(\mathrm{Cd}, \mathrm{Fe}, \mathrm{Pb}, \mathrm{Mn}, \mathrm{Zn}, \mathrm{Cr}, \mathrm{Ni}$ and $\mathrm{Cu}$ ) were significantly higher in different parts of Amaranthus hybridus, Talinum triangulare, Carica papaya, Ipomea batatas and Luffa aegyptica; and that the concentration of Cd among other heavy metals was found to be the highest in the leafy plants (Obasi et al., 2013). None of these studies considered the heavy metal absorption by Carica papaya tissue in a functional dumpsite. Besides, most of the dumpsites in Port Harcourt Metropolis are functional and lots of farming activities are going on around them to subsistently cultivate some crops especially vegetables 
(pumpkin, okro, pepper), yet some crops grow naturally and Carica papaya is inclusive. Against this background, the study examined the heavy metals uptake by Carica papaya tissues and soil in Eneka Dumpsite, Port Harcourt, Nigeria.

\section{MATERIAL AND METHODS}

\section{Study Area}

The study was carried out in Eneka Dumpsite, Port Harcourt Metropolis, Rivers State, Nigeria. The study area is located between latitude $4^{\circ} 47^{\prime} 14^{\prime \prime}$ and $5^{\circ} 06^{\prime} 58^{\prime \prime}$ 'North and longitudes $7^{\circ} 00^{\prime} 14^{\prime}$ ' East and $7^{\circ} 02$ ' $47^{\prime}$ ' East (figure 1). The criteria used in selecting the study area included proximity to the urban area, accessibility and availability of Carica papaya. Eneka Dumpsite is about $200 \mathrm{~m}$ in length and $425 \mathrm{~m}$ width tapering to about $130 \mathrm{~m}$ along Igwuruta/Eneka highway (Abah and Ohimain, 2010). The area is located in the sub-equatorial region and enjoys the tropical climate. The topography of the area ranges between $16 \mathrm{~m}$ and 40 $\mathrm{m}$ above the sea level (Mmom and Fred-Nwagwu, 2013) and has the vegetation type similar to tropical rainforest. Generally, the vegetation is consistently nourished with high rainfall and high temperature which provide favourable condition for the growth of varieties of tall and big trees like Swietenia macrophylla, Triplochiton scleroxylon, Terminalia superba, and Elaeis guineensis (Eludoyin et al., 2012). The soils of the area can be categorized as freshwater brown loams and sandy loams.

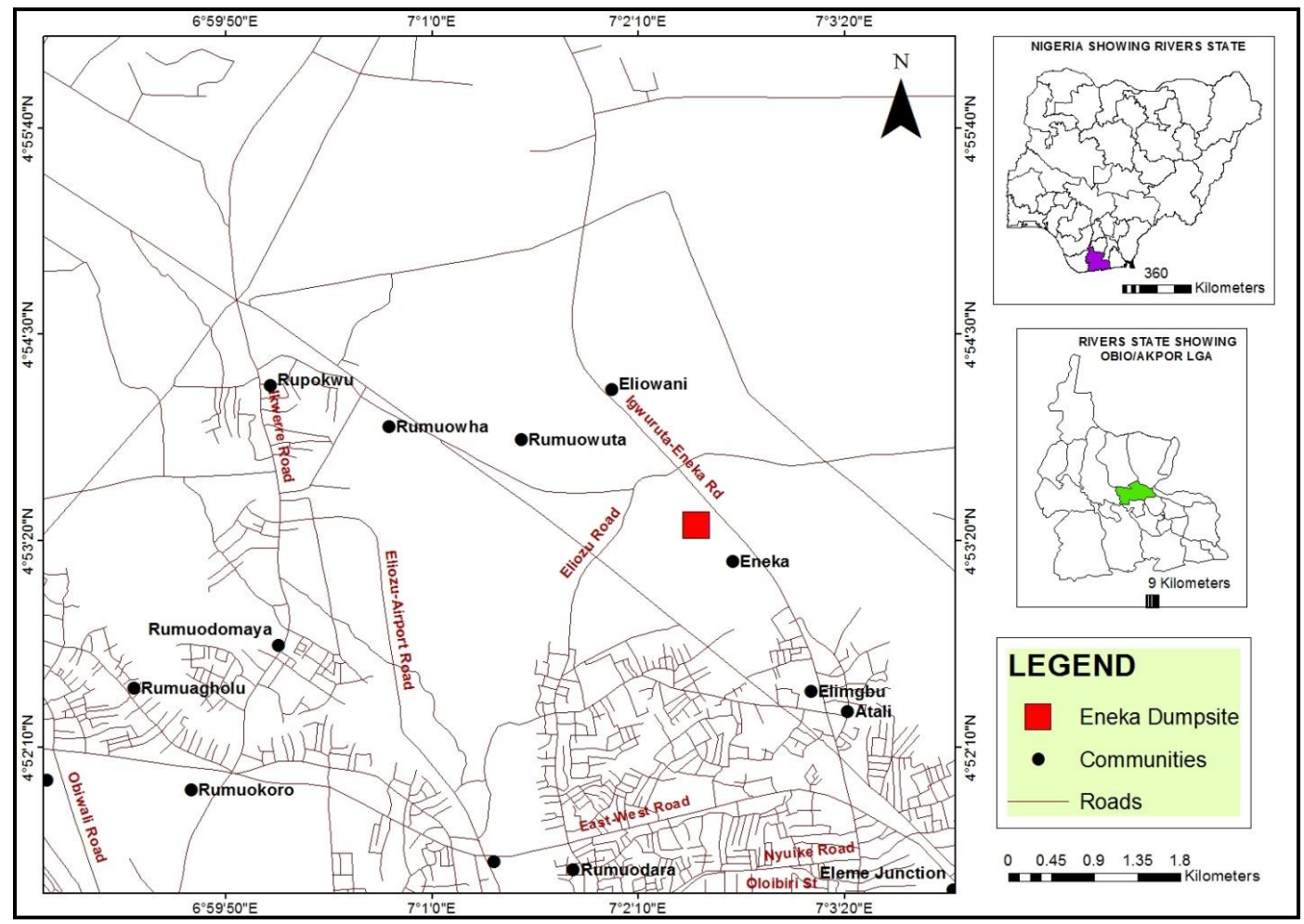

Figure 1. Port Harcourt Metropolis showing Eneka Dumpsite Location Source: Rivers State Ministry of Lands and Survey, 2019

\section{Research Design and Site Description}

The research design of this study was experimental design whereby the study made use of both experimental plot (Eneka Dumpsite) and the control plot. The experimental location of 
the study was Eneka Dumpsite while the control plot was a fallow land of about 5 years and about $300 \mathrm{~m}$ away from the dumpsite. Waste deposited at this site included plastic materials, bottles, cartons, textile materials, electrical wires, cans, leather materials, metal objects, used oil cans and commercial and domestic wastes of various compositions (Eludoyin et al., 2012; Abah and Ohimain, 2013; Mmom and Fred-Nwagwu, 2013; Avwiri and Olatubosun, 2014).

\section{Carica papaya Sampling Technique}

A transect of $100 \mathrm{~m} \times 300 \mathrm{~m}$ was laid from the center of the dumpsite. In the transect, a $20 \mathrm{~m}$ x $20 \mathrm{~m}$ quadrat was established at $10 \mathrm{~m}, 20 \mathrm{~m}, 50 \mathrm{~m}$ and $300 \mathrm{~m}$ (control) from dumpsite whereby the tissues (leaf, fruit and root) of Carica papaya were collected on the identified papaya stand (figure 1). Three Carica papaya stands of at least $10 \mathrm{~m}$ apart were sampled in each $20 \mathrm{~m} \times 20 \mathrm{~m}$ quadrat at each distance from the dumpsite. From each Carica papaya stand, 3 composite samples of each of fresh and mature leaves, mature fruits and roots were collected after being homogenized (Tigist et al., 2014). Each composite sample was properly labelled according to their stands and distance from the dumpsite. Thus, a total of 9 samples of each Carica papaya tissue were taken to the laboratory for further analysis.

\section{Laboratory Analysis for Carica papaya tissues}

The leaf, stem, fruit and root samples of Carica papaya were thoroughly washed with running tap water and rinsed with deionized water to remove any soil particles attached to the plant surfaces. The fruit samples were scrapped to separate the seed from the fruit and thereafter the fruit only were crushed. Similarly, the leaf and root was crushed. All the tissues were ovendried at $70{ }^{\circ} \mathrm{C}$ for 24 hours. After cooling at ambient temperature, the dried tissues were weighed and ground into fine powder and thereafter were kept in pre-cleaned screw capped polyethylene container for further metal concentration analysis. The sample digests of the fruit, leaf, stem and root were analyzed in five replicates for Iron $(\mathrm{Fe})$, Lead $(\mathrm{Pb})$, Nickel $(\mathrm{Ni})$, Cadmium $(\mathrm{Cd})$, and Copper $(\mathrm{Cu})$. These heavy metals were determined by Atomic Absorption Spectrophotometry (AAS) of the Association of Official Agricultural Chemists (AOAC) standard (Akinola and Adenuga, 2008). All the samples were quantified in quadruplicate. The analysis was carried out in the Agronomy Laboratory of the University of Ibadan, Ibadan, Nigeria.

\section{Soil Sampling Techniques}

A transect of $100 \mathrm{~m} \times 300 \mathrm{~m}$ was laid from the center of the dumpsite. In the transect, a $20 \mathrm{~m}$ x $20 \mathrm{~m}$ quadrat was established at $10 \mathrm{~m}, 20 \mathrm{~m}, 50 \mathrm{~m}$ and $300 \mathrm{~m}$ (control) from dumpsite whereby soil samples were collected from the topsoil $(0-15 \mathrm{~cm})$ (figure 1$)$. Three soil samples were collected around every selected Carica papaya stand into the well-labelled polythene packs. Thus, nine soil samples were collected at each distance from the dumpsite. The soil specimens were air-dried and sieved with $2 \mathrm{~mm}$ mesh for laboratory examination.

\section{Laboratory Analysis for Soil Samples}

Extracts to be used for determining heavy metals were obtained by leaching soil samples using 0.1N EDTA and $5 \mathrm{~g}$ of each sample was weighed into a clean, dry silica dish, covered and ignited in a furnace for $6 \mathrm{~h}$ at $500{ }^{\circ} \mathrm{C}$ until a grey white ash was obtained (Nwaichi et al., 2014). The cover of the dish was opened to allow for escape of gases. To cool ash samples, $5 \mathrm{ml}$ of 10 $\% \mathrm{HCl}$ was added to enhance dissolution and $5 \mathrm{ml}$ of $10 \% \mathrm{HNO}_{3}$ was added thereafter and set on a water bath to dissolve completely. The solution was later relocated into a clean dry $50 \mathrm{ml}$ standard volumetric flask and marked up with distilled water (Khan et al., 2008). Extracts used for determining heavy metals were obtained by leaching soil samples using 0.1N EDTA. The concentrations of extractable trace metals including $\mathrm{Fe}, \mathrm{Pb}, \mathrm{Ni}, \mathrm{Cd}$ and $\mathrm{Cu}$ were determined using AAS of AOACs standard (Nazli et al., 2010; Naeem et al., 2012). The blank reagent and standard reference soil materials was included in each sample batch to verify the accuracy and 
precision of the digestion procedure and also for subsequent analyses. All the samples were quantified in quadruplicate. The analysis was carried out in the Agronomy Laboratory of the University of Ibadan, Ibadan, Nigeria.

\section{Method of Data Analysis}

Descriptive and inferential statistics were used to analyze the data obtained on soil samples and tissues of Carica papaya. Analysis of variance (ANOVA) was used to determine the significant differences at $\mathrm{p}<0.05$ of heavy metals in soil and Carica papaya with respect to distances from the dumpsite. Relationships between heavy metals in the soil and tissues of Carica papaya were determined using Spearman's rank correlation statistics while scatter diagram was used to depict the correlation between the heavy metals in soil and tissues in Carica papaya. The mean values of the heavy metals in soil were compared with the permissible levels set by United States Environmental Protection Agency (USEPA), Department of Petroleum Resources (DPR) in Nigeria while that of C. papaya tissues were compared with the permissible levels of the World Health Organization (WHO). Pollution Load Index (PLI) for each study site was evaluated (Tomllinson et al., 1980). The PLI was obtained as a contamination factor (CF) of each metal with respect to the natural background value in the soil was computed using Equations (1) and (2) (Ogunmodede et al., 2016). CFs were the heavy metal loads at the baseline and CF $>1$ indicated heavy metal accumulation or pollution in soil from the test site (Agunbiade and Fawale, 2009). Translocation factors were computed for the heavy metals to quantify the efficiency of Carica papaya to accumulate in a given heavy metal and can be PLI $>1$ or PLI $<1$. When PLI $>1$, the location is being polluted and is of pollution concern (Uwah et al., 2012; Ololade, 2014).

Translocation factor (TF) was determined using the standard method (Ogunmodede et al., 2016).

$\mathrm{CF}=\mathrm{C}_{\text {sample }} / \mathrm{C}_{\text {background }}$

$\mathrm{PLI}=\left[\mathrm{CF} 1 \mathrm{x} \text { CF2 } \mathrm{x} \text { CF } 3 \mathrm{x}_{\mathrm{m}} \mathrm{x} \mathrm{CFn}\right]^{1 / n}$

where,

$\mathrm{CF}=$ contamination factor, $\mathrm{n}=$ number of metals $=5$;

Csample $=$ metal concentrate on in polluted soils;

Cbackground $=$ mean natural background value of that metal.

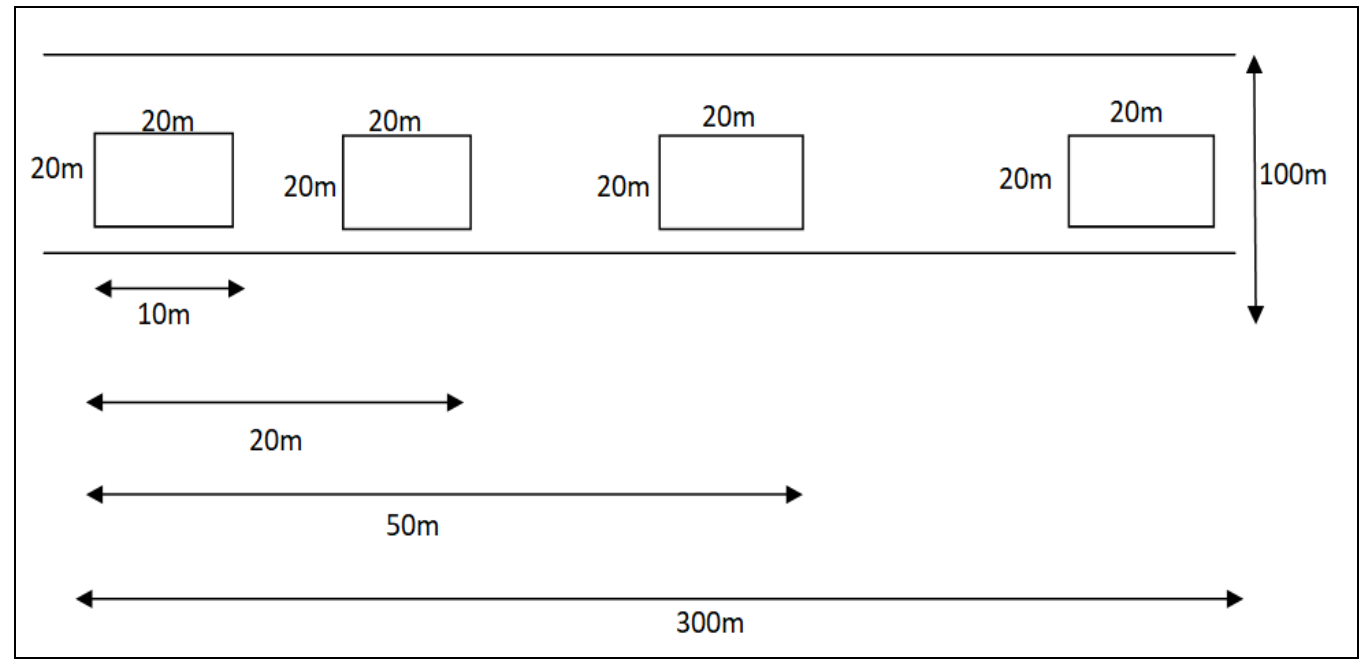

Figure 2. Layout of the sampling sites for Soil and Carica papaya sample collection Source: Researchers' Fieldwork, 2019 


\section{RESULTS}

Heavy metal uptake by Carica papaya with increasing distance from dumpsite

The findings revealed that the mean concentration of Fe decreased with increasing distance from the dumpsite. The mean concentration of Fe was lowest in the Carica papaya tissues in the control site (table 1). However, the concentration of Fe was the highest heavy metal at all the distances from the dumpsite considered for the study. The concentration of Fe was highest in the leaf at all distances from the dumpsite. More importantly, Fe concentrations at different distances from the dumpsite varied significantly among the tissues of Carica papaya $(\mathrm{F}=7.18, \mathrm{p}<0.05)$. The mean $\mathrm{Pb}$ was highest in the root of Carica papaya at $10 \mathrm{~m}(4.8 \pm 8.6 \mathrm{mg} / \mathrm{kg}) ; 20 \mathrm{~m}(3.5 \pm 0.3 \mathrm{mg} / \mathrm{kg})$ and $50 \mathrm{~m}(2.7 \pm 0.3 \mathrm{mg} / \mathrm{kg})$ of distance away from the dumpsite. In the root, leaf, and fruit; the concentrations of $\mathrm{Pb}$ decreased with increasing distance from the dumpsite. Furthermore, $\mathrm{Ni}$ and Cd were lower in concentrations compared to the level of availability of other heavy metals investigated. Their concentrations were slightly varied with increasing distance from the dumpsite. The concentration of $\mathrm{Cu}$ was highest in the root at all points of study from the dumpsite and the mean $\mathrm{Cu}$ significantly varied among the tissues in the study area $(\mathrm{F}=1.27, \mathrm{p}<0.05)$. Summarily, majority of the heavy metals were concentrated in the root, followed by the leaf and lowest in the fruit. Generally, the mean concentrations of heavy metal contents in the tissues of Carica papaya in the dumpsite occurred in the decreasing order of $\mathrm{Fe}>\mathrm{Cu}>\mathrm{Pb}>\mathrm{Ni}>\mathrm{Cd}$ (table 1). Comparing the level of concentrations of heavy metals with the WHO permissible level, $\mathrm{Fe}, \mathrm{Ni}$ and $\mathrm{Pb}$ concentrations were higher than the permissible level (table 1).

Table 1. Heavy metals in the tissues of Carica papaya at different distances from the dumpsite (Source: WHO permissible levels: Bigdeli and Selsepour, 2008; Ogunkunle et al., 2014; Hailemariam et al., 2015; Researchers' Analysis, 2019)

\begin{tabular}{|c|c|c|c|c|c|c|c|c|}
\hline \multirow[t]{2}{*}{$\begin{array}{l}\text { Parameters } \\
(\mathrm{mg} / \mathrm{kg})\end{array}$} & \multirow[t]{2}{*}{ Tissues } & $10 \mathrm{~m}$ & $20 \mathrm{~m}$ & $50 \mathrm{~m}$ & $\begin{array}{l}300 \mathrm{~m} \\
\text { (Control) }\end{array}$ & \multirow[t]{2}{*}{$\begin{array}{l}\text { F value } \\
(\mathrm{p}<0.05)^{+}\end{array}$} & \multirow[t]{2}{*}{$\begin{array}{l}\text { F value } \\
(p<0.05)^{++}\end{array}$} & \multirow[t]{2}{*}{ WHO } \\
\hline & & Mean \pm SD & Mean \pm SD & Mean \pm SD & Mean \pm SD & & & \\
\hline \multirow[t]{3}{*}{$\mathrm{Fe}$} & Root & $134.2 \pm 21.6$ & $127.1 \pm 12.3$ & $108.3 \pm 10.1$ & $98.2 \pm 6.2$ & $4.81 *$ & \multirow[t]{3}{*}{$7.18 *$} & \multirow[t]{3}{*}{425} \\
\hline & Leaf & $189 \pm 20.2$ & $156 \pm 11.2$ & $121.3 \pm 5.5$ & $98.0 \pm 7.3$ & $5.27 *$ & & \\
\hline & Fruit & $143.0 \pm 19.5$ & $106.1 \pm 15.4$ & $97.3 \pm 5.6$ & $80.0 \pm 9.3$ & $12.95^{*}$ & & \\
\hline \multirow[t]{3}{*}{$\mathrm{Pb}$} & Root & $4.8 \pm 8.6$ & $3.5 \pm 0.4$ & $2.7 \pm 0.3$ & $1.8 \pm 3.5$ & $1.25^{*}$ & \multirow[t]{3}{*}{$1.17 *$} & \multirow[t]{3}{*}{0.1} \\
\hline & Leaf & $3.7 \pm 1.6$ & $2.6 \pm 0.8$ & $2.3 \pm 0.9$ & $1.9 \pm 0.5$ & $2.14 *$ & & \\
\hline & Fruit & $3.9 \pm 1.4$ & $2.7 \pm 0.6$ & $1.8 \pm 0.2$ & $1.1 \pm 0.5$ & $2.67 *$ & & \\
\hline \multirow[t]{3}{*}{$\mathrm{Ni}$} & Root & $0.8 \pm 0.1$ & $0.6 \pm 0.1$ & $0.3 \pm 0.2$ & $0.2 \pm 0.1$ & 0.07 & \multirow[t]{3}{*}{0.29} & \multirow[t]{3}{*}{67} \\
\hline & Leaf & $0.7 \pm 0.2$ & $0.6 \pm 0.1$ & $0.3 \pm 0.1$ & $0.2 \pm 0.1$ & 0.35 & & \\
\hline & Fruit & $0.5 \pm 0.1$ & $0.4 \pm 0.1$ & $0.3 \pm 0.1$ & $0.2 \pm 0.1$ & 0.27 & & \\
\hline \multirow[t]{3}{*}{$\mathrm{Cd}$} & Root & $0.7 \pm 0.1$ & $0.5 \pm 0.1$ & $0.4 \pm 0.1$ & $0.2 \pm 1.7$ & 0.12 & \multirow[t]{3}{*}{0.68} & \multirow[t]{3}{*}{0.05} \\
\hline & Leaf & $0.7 \pm 0.2$ & $0.5 \pm 0.1$ & $0.3 \pm 0.1$ & $0.2 \pm 0.1$ & 0.91 & & \\
\hline & Fruit & $0.5 \pm 0.1$ & $0.3 \pm 0.1$ & $0.2 \pm 0.1$ & $0.1 \pm 0.0$ & 0.34 & & \\
\hline \multirow[t]{3}{*}{$\mathrm{Cu}$} & Root & $7.6 \pm 1.8$ & $7.5 \pm 1.1$ & $7.3 \pm 0.9$ & $7.2 \pm 0.8$ & 0.74 & \multirow[t]{3}{*}{$1.27 *$} & \multirow[t]{3}{*}{73} \\
\hline & Leaf & $6.1 \pm 3.8$ & $5.4 \pm 2.4$ & $5.1 \pm 2.3$ & $5.0 \pm 1.9$ & 0.75 & & \\
\hline & Fruit & $6.0 \pm 1.5$ & $5.3 \pm 0.3$ & $4.9 \pm 0.6$ & $4.7 \pm 1.9$ & 1.32 & & \\
\hline
\end{tabular}

$* \mathrm{~F}$ value is significant; $+\mathrm{F}$ value of each tissue; $++\mathrm{F}$ value of heavy metals for all tissues; SD-Standard Deviation; $\mathrm{n}=36$;

\section{Effects of dumpsite on heavy metal concentrations in soil}

The concentrations of heavy metals in soils at different distances from the dumpsite are shown in table 2. The result reveals that the concentration of Fe was $1663.0 \mathrm{mg} / \mathrm{kg}, 1571.0$ $\mathrm{mg} / \mathrm{kg}$ and $692 \mathrm{mg} / \mathrm{kg}$ at $10 \mathrm{~m}, 20 \mathrm{~m}$ and $50 \mathrm{~m}$ respectively while at the control plot, it was $605.0 \mathrm{mg} / \mathrm{kg}$. The concentrations of $\mathrm{Pb}, \mathrm{Ni}, \mathrm{Cd}$ and $\mathrm{Cu}$ also decreased with increasing distance from the dumpsite. The concentrations of heavy metals investigated varied significantly with distance from the dumpsite. The result also revealed that the concentration of Fe was the highest while Ni was the lowest at all the distances considered for this study. The concentrations of heavy metals were significantly varied with distance from the dumpsite. The concentrations of 
$\mathrm{Ni}, \mathrm{Cd}$ and $\mathrm{Cu}$ (10 m and $20 \mathrm{~m}$ away only) were higher than the permissible limit of DPR while the concentration of $\mathrm{Cd}$ at $10 \mathrm{~m}$ away from the dumpsite only was higher than the permissible limit of USEPA (table 3). The mean concentrations of heavy metal contents in soils at different distances from the dumpsite occurred in the decreasing order of $\mathrm{Fe}>\mathrm{Pb}>\mathrm{Cd}>\mathrm{Cu}>\mathrm{Ni}$ (table 2).

Table 2. Heavy metal concentrations in soils at different distances from the dumpsite

(Sources: DPR, 2002; Chiroma et al., 2014; USEPA, 2016; Researchers’ Analysis, 2019)

\begin{tabular}{|c|c|c|c|c|c|c|c|}
\hline \multirow{2}{*}{$\begin{array}{c}\text { Parameters } \\
(\mathrm{mg} / \mathrm{kg})\end{array}$} & $10 \mathrm{~m}$ & $20 \mathrm{~m}$ & $50 \mathrm{~m}$ & $\begin{array}{c}300 \mathrm{~m} \\
(\text { Control })\end{array}$ & \multirow{2}{*}{$\begin{array}{c}\text { F value } \\
(\mathrm{p}<0.05)\end{array}$} & USEPA & DPR \\
\cline { 2 - 5 } & Mean \pm SD & Mean \pm SD & Mean \pm SD & Mean \pm SD & & \\
\hline $\mathrm{Fe}$ & $1663 \pm 21.2$ & $1571.0 \pm 18.4$ & $692.0 \pm 7.8$ & $605.0 \pm 9.2$ & $13.06^{*}$ & & 5000 \\
\hline $\mathrm{Pb}$ & $220.0 \pm 8.6$ & $175.0 \pm 6.4$ & $105.0 \pm 5.2$ & $102.0 \pm 3.5$ & $5.41^{*}$ & 300 & 85 \\
\hline $\mathrm{Ni}$ & $23.0 \pm 3.1$ & $16.0 \pm 2.6$ & $12.5 \pm 1.5$ & $9.7 \pm 1.2$ & $2.91^{*}$ & & 35 \\
\hline $\mathrm{Cd}$ & $80.0 \pm 5.8$ & $65.0 \pm 4.7$ & $45.0 \pm 2.4$ & $17.5 \pm 1.7$ & $4.70^{*}$ & 70 & 0.8 \\
\hline $\mathrm{Cu}$ & $42.5 \pm 4.8$ & $39.0 \pm 4.5$ & $29.5 \pm 3.3$ & $17.7 \pm 1.9$ & $1.75^{*}$ & 250 & 36 \\
\hline
\end{tabular}

*F value is significant; SD-Standard Deviation

\section{Contamination Factor and Pollution Loading Index of Heavy Metals in Soil}

Contamination factor (CF) and pollution load index (PLI) were used to assess heavy metal contaminations in soil located in and around Eneka Dumpsite (table 3). The CF for the five metals at different distances $(10 \mathrm{~m}, 20 \mathrm{~m}$, and $50 \mathrm{~m})$ were relatively high ranging from 1.03 in $\mathrm{Pb}$ to $4.58 \mathrm{in} \mathrm{Cd}$. The analysis has also shown that the CFs decreased with increasing distance from the dumpsite. Furthermore, the $\mathrm{CF}$ of $\mathrm{Cd}$ was the highest at all distances from the dumpsite considered in this study. Thus, $\mathrm{CF}$ at the distance of $10 \mathrm{~m}, 20 \mathrm{~m}$ and $50 \mathrm{~m}$ away from the dumpsite is arranged in the decreasing order of $\mathrm{Cd}>\mathrm{Fe}>\mathrm{Cu}>\mathrm{Ni}>\mathrm{Pb} ; \mathrm{Cd}>\mathrm{Fe}>\mathrm{Cu}>\mathrm{Pb}>\mathrm{Ni}$ and $\mathrm{Cd}>\mathrm{Cu}>\mathrm{Ni}>\mathrm{Fe}>\mathrm{Pb}$ respectively. The $\mathrm{CF}$ of all the heavy metals can be grouped into very severe contamination (table 4). Nevertheless, the PLI was highest at $10 \mathrm{~m}$ distance from the dumpsite while the least was observed at $50 \mathrm{~m}$ away from the dumpsite. All PLIs were greater than unity and the values fell within moderate pollution (table 4).

Table 3. Contamination Factors (CF) of Heavy Metals in Soils around the Mechanic Workshop (Source: Researcher's Analysis, 2019)

\begin{tabular}{|c|c|c|c|c|}
\hline Heavy Metals & $10 \mathrm{~m}$ & $20 \mathrm{~m}$ & $50 \mathrm{~m}$ & $\begin{array}{c}\text { Natural Background } \\
\text { Concentration* }\end{array}$ \\
\hline $\mathrm{Fe}$ & 2.75 & 2.60 & 1.14 & $605.0 \pm 9.2$ \\
\hline $\mathrm{Pb}$ & 2.16 & 1.72 & 1.03 & $102.0 \pm 3.5$ \\
\hline $\mathrm{Ni}$ & 2.37 & 1.65 & 1.29 & $9.7 \pm 1.2$ \\
\hline $\mathrm{Cd}$ & 4.58 & 3.71 & 2.57 & $17.5 \pm 1.7$ \\
\hline $\mathrm{Cu}$ & 2.40 & 2.20 & 1.67 & $17.7 \pm 1.9$ \\
\hline PLI & $\mathbf{2 . 7 4}$ & $\mathbf{2 . 2 7}$ & $\mathbf{1 . 4 5}$ & \\
\hline
\end{tabular}

* Mean natural background concentration $( \pm \mathrm{SD}, \mathrm{n}=5)$

Table 4. Significance of intervals of contamination/pollution index (C/P) (Sources: Assuncao et al., 2003; Ogunmodede et al., 2016)

\begin{tabular}{|c|c|}
\hline Class & Contamination factor index \\
\hline$<1$ & Very slight contamination \\
\hline $0.10-0.25$ & Slightly contamination \\
\hline $0.26-0.5$ & Moderate contamination \\
\hline $0.51-0.75$ & Severe contamination \\
\hline $0.76-1.00$ & Very severe contamination \\
\hline $1.10-2.0$ & Slight pollution \\
\hline $2.1-4.0$ & Moderate pollution \\
\hline $4.1-9.0$ & Severe pollution \\
\hline $9.1-16.0$ & Very severe pollution \\
\hline$>16.0$ & Excessive pollution \\
\hline
\end{tabular}




\section{Translocation Factor (TF)}

The transfer of the heavy metals from soil to Carica papaya tissues in Eneka Dumpsite is presented in table 5. TF is the ratio of the concentration of metal in the aerial portion of the plant to the total concentration in the part in the soil. The result showed that at $10 \mathrm{~m}$ away from the dumpsite, the heavy metals occurred in this decreasing order of $\mathrm{Fe}>\mathrm{Cd}>\mathrm{Cu}>\mathrm{Pb}>\mathrm{Ni}$; at $20 \mathrm{~m}$, they follow the decreasing order of $\mathrm{Fe}>\mathrm{Ni}>\mathrm{Cd}>\mathrm{Pb}>\mathrm{Cu}$; at $50 \mathrm{~m}$, the heavy metals also occurred in the decreasing order of $\mathrm{Fe}>\mathrm{Ni}>\mathrm{Pb}>\mathrm{Cu}>\mathrm{Cd}$; while at the control plot $(300 \mathrm{~m})$, the TFs of heavy metals occurred in the decreasing order of $\mathrm{Ni}>\mathrm{Fe}>\mathrm{Pb}>\mathrm{Cd}>\mathrm{Cu}$. Translocation factors of all the heavy metals in the Carica papaya parts were higher than 1 (table 5). Thus, it may be difficult to translocate metals from the roots to the shoots and as a result, the roots may contain more concentration of the metals.

Table 5. Translocation Factor (TF) of heavy metals from soil to Carica papaya tissues (Source: Researchers' Analysis, 2019)

\begin{tabular}{|c|c|c|c|c|}
\hline \multirow{2}{*}{ Heavy Metals } & \multicolumn{4}{|c|}{ Distance } \\
\cline { 2 - 5 } & $10 \mathrm{~m}$ & $20 \mathrm{~m}$ & $50 \mathrm{~m}$ & $300 \mathrm{~m}$ \\
\hline $\mathrm{Fe}$ & 2.47 & 2.06 & 2.01 & 1.81 \\
\hline $\mathrm{Pb}$ & 1.58 & 1.51 & 1.52 & 2.67 \\
\hline $\mathrm{Ni}$ & 1.50 & 1.67 & 2.00 & 1.25 \\
\hline $\mathrm{Cd}$ & 1.71 & 1.60 & 1.41 & 1.50 \\
\hline $\mathrm{Cu}$ & 1.59 & 1.43 & & 1.35 \\
\hline
\end{tabular}

\section{Relationships between heavy metals in Carica papaya tissues and soil}

The correlations between heavy metals in soil and Carica papaya tissues were strong and positive except the relationship between $\mathrm{Fe}$ soil and $\mathrm{Fe}$ fruit; and $\mathrm{Cu}$ soil and $\mathrm{Cu}$ fruit (table 6). The coefficient of determination $\left(\mathrm{R}^{2}\right)$ of the correlations were above 0.90 except for the relationships in Fe soil and Fe fruit $\left(\mathrm{R}^{2}=0.691\right)$; Fe soil and Fe leaf $\left(\mathrm{R}^{2}=0.8919\right)$; $\mathrm{Pb}$ soil and $\mathrm{Pb}$ leaf $\left(R^{2}=0.8734\right)$; $\mathrm{Ni}$ soil and $\mathrm{Ni}$ leaf $\left(\mathrm{R}^{2}=0.8809\right)$; and $\mathrm{Cu}$ soil and $\mathrm{Cu}$ fruit $\left(\mathrm{R}^{2}=0.6979\right)$; which were observed not to be significant at $\mathrm{p}<0.05$ (table 6 ). The positive and strong correlations $(\geq 0.90)$ showed that more than $90 \%$ of the heavy metals in the tissues of Carica papaya around Eneka Dumpsite were absorbed from the soil and through the root.

Table 6. Correlations between heavy metals in soil and Carica papaya tissues

(Source: Researchers' Analysis, 2019)

\begin{tabular}{|c|c|c|c|c|c|}
\hline & Fe Soil & Pb Soil & Ni Soil & Cd Soil & Cu Soil \\
\hline Fe Root & $0.976^{*}$ & $0.964^{*}$ & 0.941 & $0.982^{*}$ & $0.980^{*}$ \\
\hline Fe Leaf & 0.944 & $0.976^{*}$ & $0.984^{*}$ & $0.978^{*}$ & $0.959^{*}$ \\
\hline Fe Fruit & 0.831 & 0.926 & $0.993^{*}$ & 0.926 & 0.884 \\
\hline Pb Root & 0.904 & $0.956^{*}$ & $0.993^{*}$ & $0.974^{*}$ & 0.947 \\
\hline Pb Leaf & 0.834 & 0.935 & $0.995^{*}$ & 0.912 & 0.867 \\
\hline Pb Fruit & 0.921 & $0.971^{*}$ & $0.994^{*}$ & $0.968^{*}$ & 0.942 \\
\hline Ni Root & $0.969^{*}$ & $0.992^{*}$ & $0.974^{*}$ & $0.960^{*}$ & 0.944 \\
\hline Ni Leaf & $0.988^{*}$ & $0.977^{*}$ & 0.939 & $0.965^{*}$ & $0.962^{*}$ \\
\hline Ni Fruit & 0.932 & $0.955^{*}$ & $0.975^{*}$ & $0.991^{*}$ & $0.975^{*}$ \\
\hline Cd Root & 0.880 & 0.922 & $0.976^{*}$ & $0.985^{*}$ & $0.963^{*}$ \\
\hline Cd Leaf & 0.944 & $0.985^{*}$ & $0.989^{*}$ & $0.963^{*}$ & 0.940 \\
\hline Cd Fruit & 0.889 & $0.959^{*}$ & $0.999^{*}$ & $0.952^{*}$ & 0.919 \\
\hline Cu Root & $0.974^{*}$ & $0.975^{*}$ & $0.957^{*}$ & $0.979^{*}$ & $0.972^{*}$ \\
\hline Cu Leaf & 0.854 & $0.957^{*}$ & $0.990^{*}$ & 0.881 & 0.835 \\
\hline Cu Fruit & 0.894 & $0.973^{*}$ & $0.998^{*}$ & 0.926 & 0.889 \\
\hline
\end{tabular}

\section{DISCUSSION}

Findings reveal that only $\mathrm{Cd}$ and $\mathrm{Pb}$ were higher in the tissues of Carica papaya than the WHO permissible levels of $0.2 \mathrm{mg} / \mathrm{kg}$ and $0.3 \mathrm{mg} / \mathrm{kg}$ respectively. The high Cd concentration in 
the tissues of Carica papaya in the study area may be attributed to the inadvertent uptake and translocation (Asuncao et al., 2003; Obasi et al., 2013) and may lead to phytotoxicity in plant (Obasi et al., 2013). Cd in soil was higher than the permissible level of DPR $(0.8 \mathrm{mg} / \mathrm{kg})$ while it was only the $\mathrm{Cd}$ at $10 \mathrm{~m}$ away from the dumpsite that was higher than the permissible levels of USEPA $(70 \mathrm{mg} / \mathrm{kg})$. The high concentration of $\mathrm{Cd}$ in the entire study area is a great concern, though higher around the dumpsite. This can be attributed to the presence of waste like battery, engine oils, metal parts such as radiator which constitute part of the waste deposited in the dumpsite (Odoh et al., 2006).

The high levels of $\mathrm{Cd}$ and $\mathrm{Pb}$ may be dangerous to human health as there is tendency of injecting the toxic substance into the food chain thereby accumulating easily in the human body. Ang et al., (2003) reported that $\mathrm{Pb}$ is known to be toxic even at low concentration especially in young children and that the ingestion of $\mathrm{Pb}$ may result to kidney disorder, brain damage, sensory disturbances. High $\mathrm{Cd}$ in the human body can also lead to kidney problem, respiratory system malfunctions, bone damage and cancer (Godt et al., 2006). Translocation factors of all the heavy metals in the Carica papaya parts were higher than 1 . Thus, it may be difficult to translocate metals from the roots to the shoots and as a result, the roots may contain more concentrations of the metals. Since the translocation factors of heavy metals in this study were greater than one, this indicated that there was high root to shoot translocation of metals in Carica papaya because translocation factors are always based on the root uptake of the heavy metals and not the foliar absorption of atmospheric metal deposits (Awode et al., 2006). This further proves that Carica papaya has the potentials to be used for phyto-extraction of the metals in the environment (Yoon et al., 2006; Cui et al., 2007). The higher contamination factor of $\mathrm{Cd}$ in the study area suggests that Cd was a major heavy metal being absorbed by plants especially Carica papaya and this confirms its high presence in the soil. The PLI of heavy metals in the study area is also found to be highest at the distance of $10 \mathrm{~m}$ from the dumpsite and reduced with the increase in distance from the dumpsite. This trend indicates that there is occurrence of dilution and dispersion of heavy metal contents through the soil with increasing distance from the source areas (Chakravarty and Patgiri, 2009). The higher values of PLI showed that anthropogenic sources contribute immensely as heavy metal sources in the study area. It was reported that lower values of PLI imply that there was no major input from anthropogenic sources (Chakravarty and Patgiri, 2009. The relationships between the heavy metals in Carica papaya and soil were positive and strong.

The results simply explained that the heavy metals accumulated in the soils are transported to the tissues of Carica papaya through their roots by the process of absorption (Uwah et al., 2012). Thus, the absorption of heavy metals in the tissues of C. papaya was greatly controlled by the content of heavy metals in the soil solution (Tigist et al., 2014).

\section{CONCLUSION}

The study has demonstrated that heavy metals especially $\mathrm{Pb}$ and $\mathrm{Cd}$ were absorbed by the tissues of Carica papaya with most of the heavy metals being absorbed by the root and leaf. The concentrations of heavy metals varied significantly with distance from the dumpsite as their concentrations in the Carica papaya tissues decreased with increasing distance from the dumpsite. The heavy metal concentrations in the tissues of $\mathrm{C}$. papaya and soil in the study area occurred in the decreasing order of $\mathrm{Fe}>\mathrm{Cu}>\mathrm{Pb}>\mathrm{Ni}>\mathrm{Cd}$; and $\mathrm{Cd}$ had the highest contamination factor despite its lowest presence in the soil samples. Positive and strong correlations existed between the heavy metals in the tissues of $\mathrm{C}$. papaya and heavy metal contents in soil except the correlations between $\mathrm{Fe}$ soil and Fe leaf; and $\mathrm{Cu}$ soil and $\mathrm{Cu}$ fruit. Thus, consuming any tissue or part of Carica papaya grown or surviving close to the dumpsite may lead to accumulation of the heavy metals in the body and can cause human ailments such as kidney disorder, brain damage, reductive system malfunction and disturbance of the respiratory organs. The study therefore recommended that the human consumption of C. papaya tissues especially the root and leaf for medicinal purposes around the dumpsite $(\leq 50 \mathrm{~m}$ away) should be discouraged. 
Government and waste disposal agencies should prevent indiscriminate disposal of wastes especially those that may be the sources of heavy metals. In addition, government can intensify efforts to deliberately grow Carica papaya around the dumpsite not for human consumption but to be used for phyto-extraction because of its potentials to absorb heavy metals.

\section{REFERENCES}

Abah, S.O., \& Ohimain, E. (2010). Assessment of dumpsite rehabilitation potential using the integrated risk based approach: a case study of Eneka, Nigeria. World Applied Sciences Journal, 8(4), 436-442.

Adewole, A.T. (2009). Waste management towards sustainable development in Nigeria: A case study of Lagos State. International NGO Journal, 4(4), 173-179.

Agunbiade, F.O., \& Fawale, A.T. (2009). Use of Siam weed biomarker in assessing heavy metal contamination in traffic and solid waste polluted areas. International Journal of Environmental Science \& Technology, 6(2), 267-278

Akinola, M.O., \& Adenuga, A.A. (2008). Determination of the levels of some heavy metals in african pear (Dacryodes edulis) marketed in Lagos metropolis, Nigeria. Journal of Applied Sciences and Environmental Management, 12(1), 33-37.

Aladesanmi, O.T., Agboola, F.K., \& Adeniyi, I.F. (2016). Distribution of heavy metals in surface sediments from streams and their associated fishponds in Osun State, Nigeria. Journal of Health and Pollution, 6(11), 34-46.

Amadi, A.N., \& Nwakwoala, H.O. (2013). Evaluation of heavy metal in soils from Enyimba Dumpsite in Aba, Southeastern Nigeria using contamination factors and geo-accumulation index. Energy and Environment Research, 3(1), 125-134

Amadi, A.N., Ameh, M.I., \& Jisa, J. (2010). The impact of dumpsites on groundwater quality in Markurdi Metropolis, Benue State. Natural and Applied Sciences Journal, 11(1), 90-102.

Ang, H.H., Lee, E.F., \& Matsumato, K. (2003). Analysis of Lead Contents in Herbal Preparation in Malaysia. Human and Toxicology. 22(8), 445-451.

Assuncao, A.G.L., Schat, H., \& Aarts, M.G.M. (2003). Thlaspi caerulescens, an attractive model species to study heavy metal hyper-accumulation in plants. New Phytologist, 159, 351-360.

Avwiri, G.O., \& Olatubosun, S.A. (2014). Assessment of environmental radioactivity in selected dumpsites in Port Harcourt, Rivers State, Nigeria. International Journal of Scientific \& Technology Research, 3(4), 263-269.

Awode, U.A., Uzairu, A., Balarabe, M.L., Okunola, O.J., \& Adewusi, S.G. (2008). Levels of some Trace Metals in the Fadama Soils and Pepper (Capsicum annuum) along the bank of River Challawa, Nigeria. Asian J. Sci. Res.1 - 6.

Awomeso, J.A., Taiwo, A.M., Gbadebo, A.M., \& Arimoro, A.O. (2010). Waste disposal and pollution management in urban areas: A workabale remedy for the environment in developing countries. American Journal of Environmental Sciences, 6(1), 26-32.

Bigdeli, M., \& Seilsepour, M. (2008). Investigation of metals accumulation in some vegetables irrigated with waste water in Shahre Rey-Iran and toxicological implications. Journal of Agriculture and Environmental Science, 4, 86-92.

Chakravarty, M., \& Patgiri, A. D. (2009). Metal pollution assessment in sediments of the Dikrong River, NE India. Journal of Human Ecology, 27(1), 63-67.

Chiroma, T.M., Ebewele, R.O., \& Hymore, F.K. (2014). Comparative assessment of heavy metal levels in soil, vegetables and urban grey waste water used for irrigation in Yola and Kano. International Refereed Journal of Engineering and Science, 3(2), 01-09.

Cui, S., Zhou, Q., \& Chao, L., (2007). Potential hyper-accumulation of $\mathrm{Pb}, \mathrm{Zn}, \mathrm{Cu}$ and $\mathrm{Cd}$ in endurant plants distributed in an old semetery, northeast, China. Environmental Geology 51, 1043-1045.

Department of Petroleum Resources (DPR), (2002). Nigeria environmental guidelines and standards for the petroleum industry in Nigeria (EGASPIN) (revised edition). Department of Petroleum Resources, Ministry of Petroleum and Mineral Resources, Abuja, Nigeria, 1-415.

Eludoyin, O.S., Utang, P.B., \& Obafemi, A.A. (2012). GIS, urban forestry and climate change: a review. Research Journal of Environmental and Earth Sciences. 4(6), 307-313.

Eshalomi-Mario, T.N., \& Tanee1, F.B.G. (2015). Phytodiversity assessment in abandoned solid waste dumpsites in Port Harcourt, Nigeria. Annual Research and Review in Biology, 6(6), 379-389.,

Godt, J., Scheidig, F., Grosse-Siestrup, C., Esche, V., Brandenburg, P., Reich, A., \& Groneberg, D. A. (2006). The toxicity of cadmium and resulting hazards for human health. Journal of occupational medicine and toxicology, 1(1), 1-6.

Hailemariam, T., Aregahegn, A., Bekele, T., \& Madhusudhan, A. (2015). Investigation of the levels of selected metals in edible and medicinal fruits grown in Dilla, Ethiopia. Research Journal of Chemical and Environmental Sciences, 3(4), 44-53.

Herman, G.V., Gaceu, O., Mester, C., Baias, S., Caciora, T., \& Wendt, J.A. (2019a). Spatial analysis of water quality in natura 2000 Sites Bihor, Romania. Journal of Environmental Protection and Ecology, 20(4), 2121-2129.

Herman, G.V., Ilies, D.C., Gaceu, O., Ilies, A., Mester, C., Ilies, M., \& Dumitru, M. (2019b). Some considerations concerning the quality of groundwater in the Natura 2000 Lunca Barcaului (Barcaului Meadow) site, Romania. Journal of Environmental Protection and Ecology, 20(3), 1102-1109.

Herman, G.V., Ilies, D.C., Sonko, S.M., Gaceu, O., Ilies, A., Josan, I., Mester, C. (2019c). Study regarding the quality of undersground water within Natura 2000 Cefa site (ROSCI 0025), Romania. Bulletin of L.N. Gumilyov Eurasian National University. Chemistry. Geography. Ecology Series, 129(4), 91-99. 
Khan, S., Cao, Q., Zheng, Y.M., Huang, Y.Z., \& Zhu. Y.G. (2008). Health risks of heavy metals in contaminated soils and food crops irrigated with wastewater in Beijing, China. Environmental Pollution, 152, 686-692.

Kouznetsova, M., Hauang, Z., Ma, J., Lessner, L., \& Carpenter, D. (2007). Increased rate of hospitalization for diabetes and residential proximity of hazardous waste sites. Environmental Health Perspectives, 115, 75-85.

Magaji, J. Y. (2012). Effects of waste dump on the quality of plants cultivated around Mpape dumpsite FCT Abuja, Nigeria. Ethiopian Journal of Environmental Studies and Management, 5(4), 567-573.

Mmom, P.C., \& Fred-Nwagwu, F.W. (2013). Analysis of landuse and landcover change around the city of Port Harcourt, Nigeria. Global Advanced Research Journal of Geography and Regional Planning, 2(5), 076-086

Musa, S.D., Ifatimehin O.O. (2013). Human health implications of waste dump cultivated vegetables in Anyigba, Kogi State, Nigeria Research Journal of Environmental and Earth Sciences, 5(12), 710-713.

Naeem, K., Yawar, W., Akhter, P., \& Rehana, I. (2012). Atomic absorption spectrometric determination of cadmium and lead in soil after total digestion. Asia-Pacific Journal of Chemical Engineering, 7, 295-301.

Nagarajan, R., Thirumalaisamy, S., \& Lakshumanan, E. (2012). Impact of leachate on groundwater pollution due to nonengineered municipal solid waste landfill sites of erode city, Tamil Nadu, India. Iranian Journal of Environmental Health Science and Engineering, 9(1), 35.

Najib, N.W.A.Z., Mohammed, S.A., Ismail, S.A., \& Ahmad, W.A.A.W. (2012). Assessment of heavy metal in soil due to human activities in Kangar, Perlis, Malaysia. International Journal of Civil \& Environmental Engineering, 12(6), 28-33.

Nazli, M.F., \& Hashim N.R. (2010). Heavy Metal Concentrations in an important mangrove species, Sonneratia caseolaris, in Peninsular Malaysia, Environment Asia, 3, 50-55.

Njagi, J.M. (2013). Assessment of heavy metal concentration in the environment and perceived health risks by the community around Kadhodeki Dumpsite, Nairobi County. Doctoral Dissertation, School of Public Health of Kenyatta University, 163 p.

Nubi, O.A., Osibanjo, O., \& Nubi, A.T. (2009), Impact assessment of dumpsite leachate on the qualities of surface water and sediment of River Eku, Ona-ara Local Government, Oyo State, Nigeria. Science World Journal, 3(3), 17-20.

Nwaichi, E.O., Wegwu, M.O., \& Nwosu, U.L. (2014). Distribution of selected carcinogenic hydrocarbon and heavy metals in an oil-polluted agriculture zone. Environ Monit Assess, 186, 8697-8706.

Obasi, N.A., Akubugwo, E., Kalu, K.M., Ugbogu, A.E., \& Okorie, U.C. (2013). Toxicological assessment of various metals on selected edible leafy plants of Umuka and Ubahu dumpsites in Okigwe of Imo State, Nigeria. Journal of Experimental Biology and Agricultural Sciences 1(6), 441-453.

Odoh, R., Agbaji, E.B., Kagbu, J.A. (2016). Assessment of trace metals pollution in auto-mechanic workshop in some selected local government area of Benue State, Nigeria. International Journal of Chemistry, 3(4), 78-88.

Ogunkunle, A.T.J., Bello, O.S., \& Ojofeitimi, O.S. (2014). Determination of heavy metal contamination of street-vended fruits and vegetables in Lagos State, Nigeria. International Food Research Journal, 21, 2115-2120.

Ogunmodede, O.T., Ojo, A.A., \& Jegede, R.O. (2016). Evaluation of pollution loads in and around municipal solid waste dumpsite. World Applied Sciences Journal, 34(6), 720-732,

Olayiwola, O.A., \& Onwordi, C.T. (2015). Environmental fate of heavy metals in soil of ido-osun waste dumpsite, Osogbo, Osun, Nigeria. American Journal of Environmental Protection, 3(1), 1-4.

Ololade, I.A. (2014). An assessment of heavy metal contamination in soils within auto-mechanic workshops using enrichment and contamination factors with geo-accumulation indexes, Journal of Environmental Protection, 5, 970-982

Pruss-Ustun, A., \& Corvalán, C. (2006). Preventing disease through healthy environments. Towards an estimate of the environmental burden of disease. Geneva: WHO.

Romocea, T., Oneț, A., Sabău, N.C., Oneț, C., Herman, G.V., \& Pantea, E. (2018), Change of the groundwater quality from industrial area Oradea, Romania, using Geographic Information Systems (GIS). Environmental Engineering \& Management Journal (EEMJ), 17(9), 2189-2199.

Rotich, K.H., Zhao, Y., \& Dong, J. (2006). Municipal solid waste management challenges in the developing countriesKenyan case study. Waste Management, 26, 92-100.

Tigist, M., Rao, M.V., \& Faye, G. (2014). Determination of essential and non-essential metals concentration in papaya (Carica papaya) seeds, leaves and supporting soil of Odo-Shakiso district in South East Oromia Region, Ethiopia. International Journal of Research in Pharmacy and Chemistry. 4(1), 202-216.

Tomllinson, D.C., Wilson, J.G., Harris, C.R., \& Jeffrey, D.W. (1980). Problems in the assessment of heavy metals levels in estuaries and the formation of pollution index. Helgoländer Wissenschaftliche Meeresuntersuchungen, 33, 566-569.

Ukpong, E.C., Antigha, R.E., \& Moses, E.O., (2013). Assessment of heavy metals content in soils and plants around waste dumpsites in Uyo Metropolis, Akwa Ibom State. The International Journal of Engineering and Science, 2(7), 75-86.

USEPA (2016). Suplemental guidance for developing soil screening levels for superfund sites. 187P. Available at https://nepis.epa.gov

Uwah, E.I., Gimba, M.S.B., \& Gwaski, P.A. (2012). Determination of Zn, Mn, Fe and Cu in spinach and lettuce cultivated in Potiskum, Yobe State, Nigeria. Journal of Agricultural Economics and Development, 1(4), 69-74.

Yoon, J., Cao, X., Zhou, Q., \& Ma, L.Q. (2006). Accumulation of $\mathrm{Pb}, \mathrm{Cu}$ and $\mathrm{Zn}$ in native plants growing on a contaminated Florida Site. Science of the Total Environment, 368, 456-464.

Submitted:

February 02, 2020
Revised:

June 07, 2020
Accepted and published online July 27, 2020 